\title{
An Electrochemical Study of the Effect of $B$ on the Corrosion of Atomized Fe40Al Intermetallics in Molten $\mathrm{Na}_{2} \mathrm{SO}_{4}$
}

\author{
J.G. Gonzalez-Rodriguez' ${ }^{1}$ O.L. Arenas ${ }^{2}$, J. Porcayo-Calderon ${ }^{3}$, V.M. Salinas-Bravo ${ }^{3}$, M. Casales ${ }^{4}$, \\ and A. Martinez-Villafañe ${ }^{2}$ \\ ${ }^{1}$ UAEM+CIICAP, 'Av. Universidad 1001, Col. Chamilpa, 62210-Cuernavaca, Mor., Mexico \\ ${ }^{2}$ CIMAV, Miguel de Cervantes 120, 31109, Chihuahua, Mexico \\ ${ }^{3}$ IIE, Av. Reforma H3, Temixco, Mor. \\ ${ }^{4}$ UNAM-CCF, 'Av. Universidad, S/N, Col. Chamilpa, 62209-Cuernavaca, Mor., Mexico
}

(Received March 16, 2006;:final form March 29, 2006)

\begin{abstract}
The hot corrosion resistance of sprayed and atomized and $\mathrm{Fe} 40 \mathrm{Al}+10 \mathrm{Al}_{2} \mathrm{O}_{3}$ intermetallic materials with different boron contents $(0.1,0.2$ and 0.4 at.\%) has been evaluated in molten $\mathrm{Na}_{2} \mathrm{SO}_{4}$ at 1173 and $1273 \mathrm{~K}$ using polarization curves, open circuit potential and linear polarization resistance measurements. The results are supported by electron microscopy and microchemical studies. Generally speaking, the additions of up to $0.4 \mathrm{~B}$ were berneficial, since, for short times, they made the $E_{\text {con }}$ value more active but, after some hours, all the $E_{\text {corr }}$ values became nobler, even nobler than the alloy without boron and decreased both the anodic and cathodic current density, but did not promote the formation of a passive film, at least for short times. In terms of corrosion rate, additions of boron always decreased this value as opposed to the alloy without boron, specially at $1273 \mathrm{~K}$, but the corrosion rate values decreased rapidly, attaining a constant value, which was consistent with the establishment of a protective alumina, $\mathrm{Al}_{2} \mathrm{O}_{3}$ layer and promoted $\mathrm{Al}$ depletion on the FeAl matrix which allows internal sulfidaton. It seems that the optimum amount of boron that gives the best corrosion resistance is $0.1 \mathrm{~B}$
\end{abstract}

Key words: deposited $\mathrm{Fe} 40 \mathrm{Al}$, molten $\mathrm{Na}_{2} \mathrm{SO}_{4}$, electrochemical techniques.

\section{INTRODUCTION}

Corrosion in molten salts is a small factor in corrosion of aqueous systems, but without a doubt it is an important area of the corrosion in industrial fields. Molten salts can cause corrosion by i) diffusion in solution of the constituents of the structural material, electrochemical reactions, ii) mass transport due to thermal gradients, iii) the reaction of the constituents of the molten salt with the alloy, and iv) by the reaction of the impurities in the salt with the alloy /1/. In particular, the damage that is generated by corrosion in heat exchangers systems, incinerators, burners, is in great measure caused by molten salts. Several alloys and materials have been evaluated in corrosive environments at high temperatures in salts and mixtures of salts like potassium sulfate $\left(\mathrm{K}_{2} \mathrm{SO}_{4}\right)$ and vanadium pentoxide $\left(\mathrm{V}_{2} \mathrm{O}_{5}\right) / 2 /$ mixtures of sodium sulphate and vanadium pentoxide $\left(\mathrm{Na}_{2} \mathrm{SO}_{4}+\mathrm{V}_{2} \mathrm{O}_{5}\right), 13 /$ sulphates, chlorates and carbonates $/ 4,5 /$.

Intermetallic materials have a melting point, characteristics and properties different from the original elements. Fe40Al-base intermetallics in the presence of molten salts present better corrosion resistance when comparing them with common alloys $/ 6 /$. The Fe40(at.\%)Al-base intermetallics have been evaluated in a mixture of molten salts of $80 \mathrm{wt} . \% \mathrm{~V}_{2} \mathrm{O}_{5}+20 \mathrm{wt} \%$ $\mathrm{Na}_{2} \mathrm{SO}_{4}$ at $873,973,1073$ and $1273 \mathrm{~K}$, and it was 
concluded that the formation of an aluminum oxide $\left(\mathrm{Al}_{2} \mathrm{O}_{3}\right)$ layer plays an important part in the protection against corrosion $/ 7 /$ and addition of $0.1 \mathrm{~B}$ increased the corrosion resistance. The same intermetallics were evaluated in $\mathrm{NaVO}_{3}$ at 898 and 973 , where the main cause of the reduction of the corrosion rate was the fast formation of a layer of $\mathrm{Al}_{2} \mathrm{O}_{3}$ that is increased as the temperature increases $/ 8 /$. Similar results were obtained by Tortorelli /9/ for $\mathrm{Fe}_{3} \mathrm{Al}_{2} \mathrm{Cr}$ alloy in molten $\mathrm{Na}_{2} \mathrm{SO}_{4}$ at 923 and 973 during 800 hours.

The corrosion of iron aluminides in molten $\mathrm{NaNO}_{3}\left(\mathrm{KNO}_{3}\right)-\mathrm{Na}_{2} \mathrm{O}_{2}$ at $923 \mathrm{~K}$ proceeds by oxidation, and a low release from an aluminide-rich product layer into the salt such that the compositions with higher aluminium concentrations yielded significantly better corrosion resistance $/ 10 /$. The preliminary results of the exhibition of the $\mathrm{FeAl}$ in molten $\mathrm{NaCl}-\mathrm{Na}_{2} \mathrm{CO}_{3}$ at 1173 $\mathrm{K}$ (used as an oxidiser for waste disposal), showed significantly better corrosion resistance of this aluminide than that for Inconel $873 \mathrm{~K} / 11$.

The objective of this work was to study the corrosion resistance of atomized $\mathrm{Fe} 40 \mathrm{Al}$ intermetallics with different boron contents in sodium sulfate $\left(\mathrm{Na}_{2} \mathrm{SO}_{4}\right)$ since addition of $0.1 \mathrm{~B}$ increased its corrosion resistance using and this element improves its ductility /12/. Since a molten salt acts as an electrolyte, electrochemical techniques such as potentiodynamic polarization curves, open circuit potential and linear polarization resistance (LPR) measurements can be used.

\section{EXPERIMENTAL PROCEDURE}

The materials tested here were atomized $\mathrm{Fe}$ 40 at. $\% \mathrm{Al}+10 \mathrm{Al}_{2} \mathrm{O}_{3}$, with and without boron (B)0.1(at.\%), 0.2 and 0.4 A master alloy of Fe $40 \mathrm{Al}$ was fabricated employing iron and aluminium, both of $99.99 \%$ purity. The alloy was cast in an induction furnace under an argon atmosphere and it was poured by gravity into a cylindrical graphite mold of $4 \mathrm{~cm}$ diameter. Small pieces were cut of master alloy bar, and fed to the spray atomization and deposition system. Boron with a purity of $99.99 \%$ in the form of $\mathrm{Ni}_{2} \mathrm{~B}$ was used as a microalloying constituent. The reinforcement phase was commercially pure $(99.99 \%)$ single crystal $\alpha$ $\mathrm{Al}_{2} \mathrm{O}_{3}$ platelets with an average diameter of $3 \mu \mathrm{m}$. The synthesis of the Fe40Al alloy and experimental variables used for spray atomisation and deposition are described elsewhere $/ 12 /$. Electrochemical techniques included potentiodynamic polarization curves and LPR measurements. Details of the experimental set-up for the electrochemical cell used in this work are given elsewhere 77 . The body of the cell was a $15 \mathrm{ml}$ silica crucible. The most important elements are: a reference electrode, made of $0.5 \mathrm{~mm}$ diameter platinum wire inside a mullite tube and filled with a refractory cement (Fig. I). In order to check if it was stable, another platinum electrode was immersed in the working salt and the potential of the first electrode was monitored with time once the temperature was stabilised. This potential at beginning was $30 \mathrm{mV}$ more noble than the second platinum electrode, but after 40-50 min. this difference was very stable, having a fluctuation of \pm 2 $\mathrm{mV}$. As an auxiliary electrode, another platinum electrode was used, exactly the same as the reference electrode, and as working electrode, a cylindrical piece of the intermetallic material having $3 \mathrm{~mm}$ length and 8 $\mathrm{mm}$ in diameter inside a mullite tube and filled with the

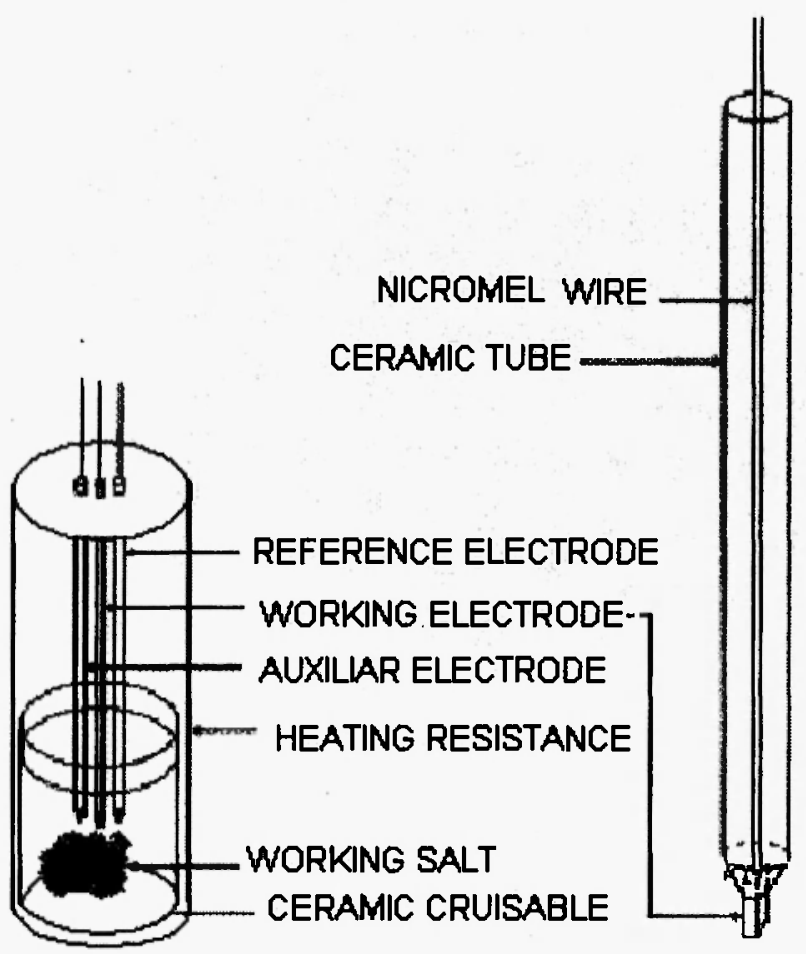

Fig. 1: Schematic diagram showing the experimental set up. 
same cement. The amount of molten salt in each run was $5 \times 10^{3} \mathrm{~g} / \mathrm{m}^{2}$. The electrical contact was made by welding an 80 mass $\% \mathrm{Cr}-20 \mathrm{Ni}$ (Nicromel) wire to the specimen. A tube furnace with capacity up to 1373 $\mathrm{K}$ was used for all the experiments. An automated potentiostat was used for all the electrochemical measurements.

The working salt was analytical grade $\mathrm{Na}_{2} \mathrm{SO}_{4}$. Prior to use, the specimens were polished with 1200-grade emery paper, washed with distilled water and degreased with acetone. All the experiments were performed in static air. The tests lasted 5 days, and the LPR measurements were taken every $30 \mathrm{~min}$. The specimens were polarized at $\pm 10 \mathrm{mV}$ with respect to the free corrosion potential $\left(E_{c o r r}\right)$ at a scan rate of $1 \mathrm{mV} / \mathrm{s}$; the same rate was used in the polarization curves. The testing temperatures were 1173 and $1273 \mathrm{~K}$. Energy dispersive of X-ray (EDX) studies were obtained from mounted and polished specimens using a scanning electronic microscope (SEM)/EDX system.

\section{RESULTS}

The stability of a platinum reference electrode was measured by measuring its free corrosion potential versus another identical platinum reference electrode and the results are shown in Fig. 2. We can see that during the first ten minutes the potential value increases

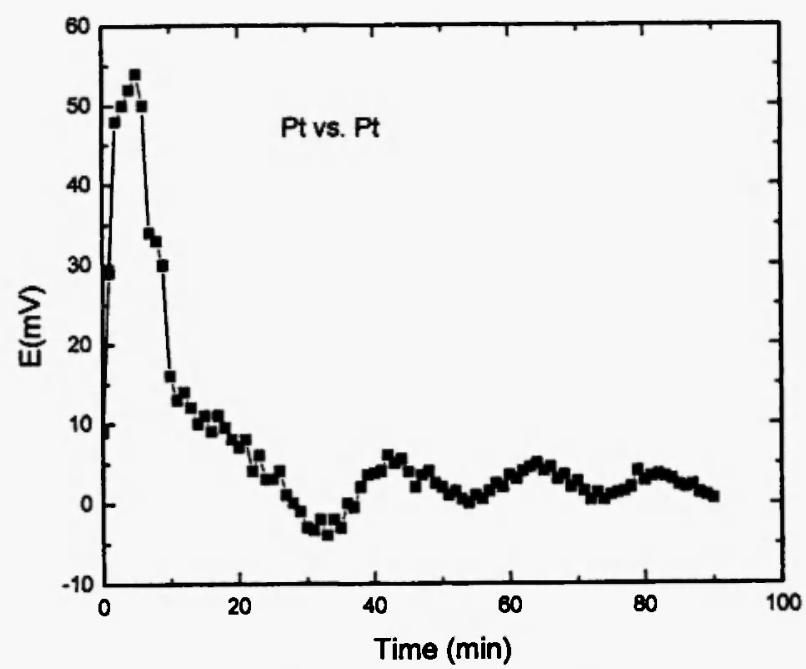

Fig. 2: Potential fluctuations of a platinum reference electrode versus another platinum reference electrode. up to $55 \mathrm{mV}$ more positive, but after this, the potential value drops and reaches a more or less stable value after approximately one hour or so.

Potentiodynamic polarization curves for the three intermetallic materials in $\mathrm{Na}_{2} \mathrm{SO}_{4}$ are observed in Fig. 3. At $1173 \mathrm{~K}$, the alloy without boron had a much higher, almost $600 \mathrm{mV}$, free corrosion potential, $E_{\text {corr }}$ value, whereas the $E_{\text {corr }}$ value of the alloy with $0.4 \mathrm{~B}$ was located very close to the value of the $0.2 \mathrm{~B}$ containing alloy laid around $-1100 \mathrm{mV}$. The Fe40Al+0.1B alloy exhibited the most active $E_{\text {corr }}$ value, approximately $1200 \mathrm{mV}$. The anodic current densities were higher for the alloy without $B$ by almost two orders of magnitude, followed by the $0.1 \mathrm{~B}$ alloy, whereas the other two alloys had very similar current density values. At $1273 \mathrm{~K}$, Fig. 4 , the behavior was very similar, but the alloy with $0.4 \mathrm{~B}$ contents has now the most active $E_{\text {cor }}$ value, around $-1500 \mathrm{mV}$, whereas the alloy with $0.1 \mathrm{~B}$ has now the most noble $E_{\text {corr }}$ value, $-1100 \mathrm{mV}$, still more active than the alloy without boron, which again had the highest anodic and cathodic current densities values. Apparently the alloys did not show a passive behavior at this stage of the tests.

The changes of the open circuit potential values, $\mathrm{E}_{\text {corr }}$, with time for the three alloys at $1173 \mathrm{~K}$ are shown in Fig. 5. It can be seen that at the beginning the base material, the alloy without boron, had more noble $\mathrm{E}_{\text {corr }}$ values, but after a few hours, the $E_{\text {cor }}$ values of all the

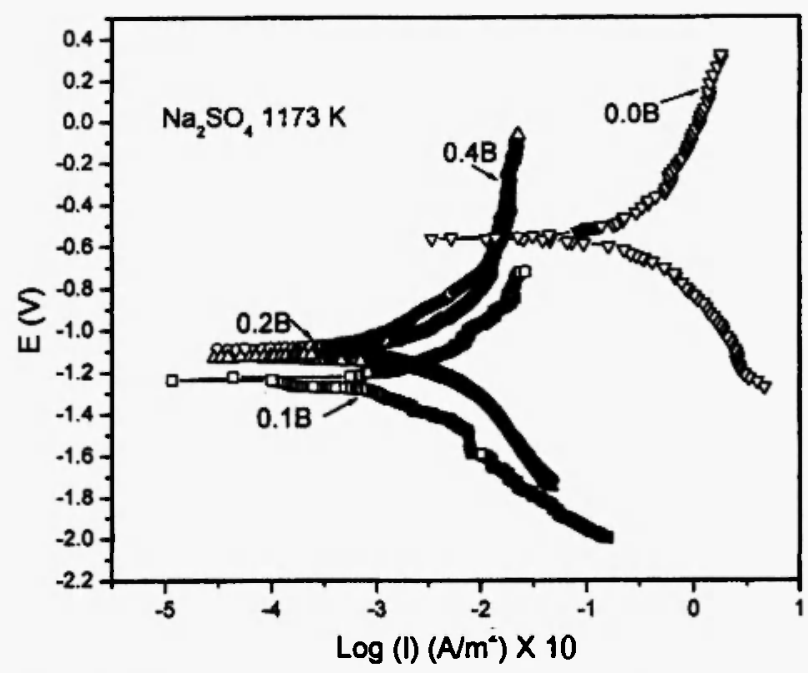

Fig. 3: Polarization curves of Fe40Al-base intermetallics in $\mathrm{Na}_{2} \mathrm{SO}_{4}$ at $1173 \mathrm{~K}$. 


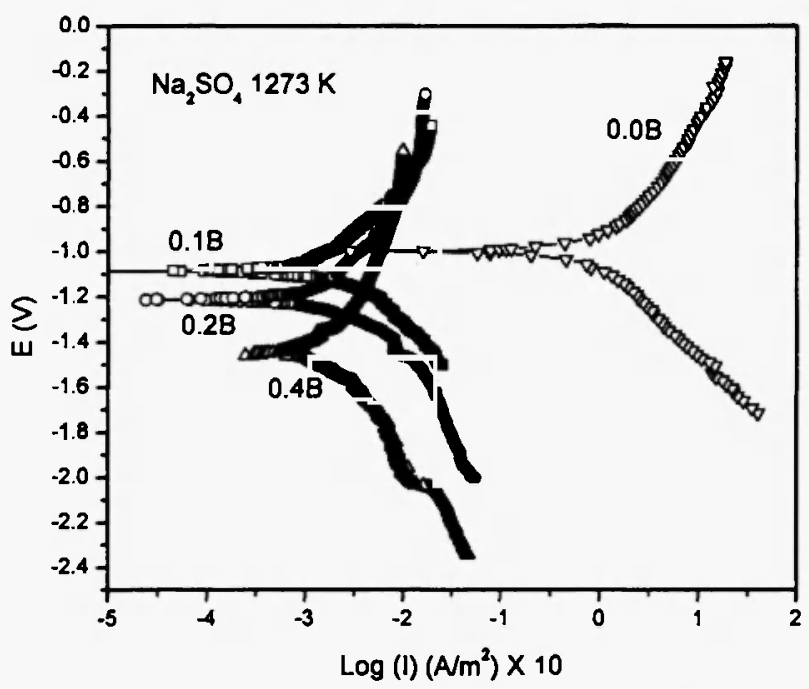

Fig. 4: Polarization curves of Fe40Al-base intermetallics in $\mathrm{Na}_{2} \mathrm{SO}_{4}$ at $1273 \mathrm{~K}$.

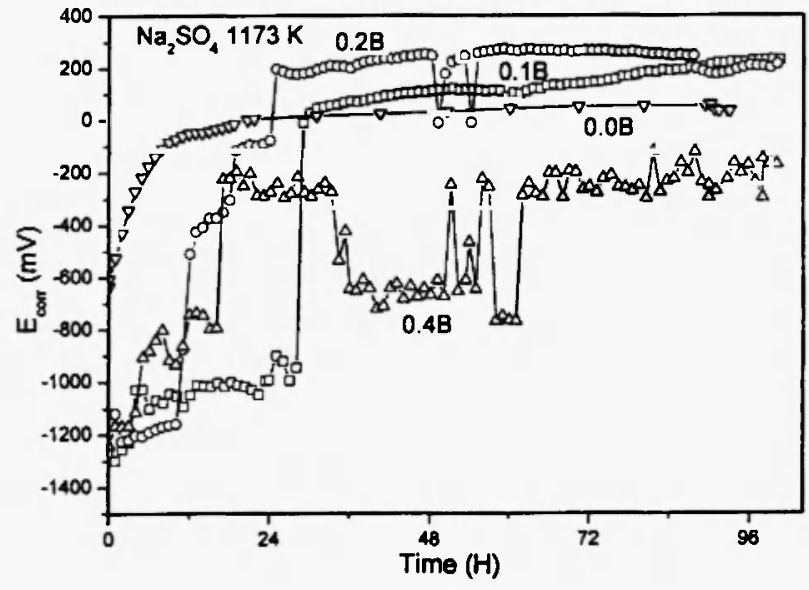

Fig. 5: Change of $E_{\text {corr }}$ with time for Fe40Al-base intermetallics in $\mathrm{Na}_{2} \mathrm{SO}_{4}$ at $1173 \mathrm{~K}$.

alloys moved towards more noble values, especially the alloys with 0.1 and $0.2 \mathrm{~B}$, which even had more noble $\mathrm{E}_{\text {corr }}$ values than the base alloy. The alloy with $0.4 \mathrm{Bshowed}$ an irregular behavior, since the $\mathrm{E}_{\mathrm{corr}}$ value also moves towards more noble values, it decreases towards more negative, active values, and, finally, it remains in more active values. The most noble value was for the alloy with $0.2 \mathrm{~B}$, very close to that for the alloy with $0.1 \mathrm{~B}$, and the most active value was for the $0.4 \mathrm{~B}$ containing alloy. The difference between the initial and final values is for up to $1000 \mathrm{mV}$.

AT $1273 \mathrm{~K}$ (Fig. 6) a similar behavior was observed, the $E_{\text {corr }}$ values move towards more noble values, this time for more than $1000 \mathrm{mV}$, although the value for the $0.1 \mathrm{~B}$ containing alloy remained constant after an initial shift towards more positive values. This time the most active value was for the alloy with $0.2 \mathrm{~B}$ whereas the noble one was the one containing $0.4 \mathrm{~B}$. This shift towards more noble $E_{\text {corr }}$ values is related to the formation of a passive, protective, film, and, in the case of $\mathrm{Al}$-containing alloys, to the presence of an external, protective alumina, $\mathrm{Al}_{2} \mathrm{O}_{3}$ film.

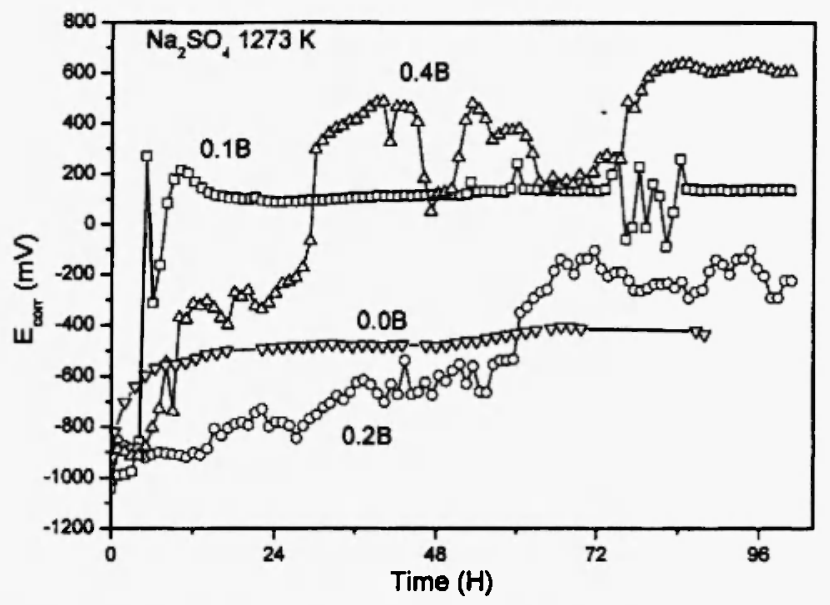

Fig. 6: Change of $E_{\text {corr }}$ with time for Fe40Al-base intermetallics in $\mathrm{Na}_{2} \mathrm{SO}_{4}$ at $1273 \mathrm{~K}$.

Polarization curves are important because from them the anodic $\left(b_{a}\right)$ and cathodic $\left(b_{c}\right)$ slopes can be used to calculate the corrosion current density $\left(I_{\text {corr }}\right)$ in terms of the polarization resistance, $R_{l p}$ obtained form the LPR experiments according to the Stearn-Geary equation 113/:

$$
I_{c o r r}=\frac{B}{R_{l p}}
$$

where

$$
B=\frac{b_{a} \cdot b_{c}}{2.303\left(b_{a}+b_{c}\right)}
$$

The values of $I_{\text {corr }}$ obtained from the LPR tests are shown in Figs. 7 and 8. At $1173 \mathrm{~K}$, all the alloys, although initially showed high $I_{\text {corr }}$ values, specially the base alloy, very soon reached very similar, constant, $I_{\text {cor }}$ values. Apparently, within the experimental error, the 


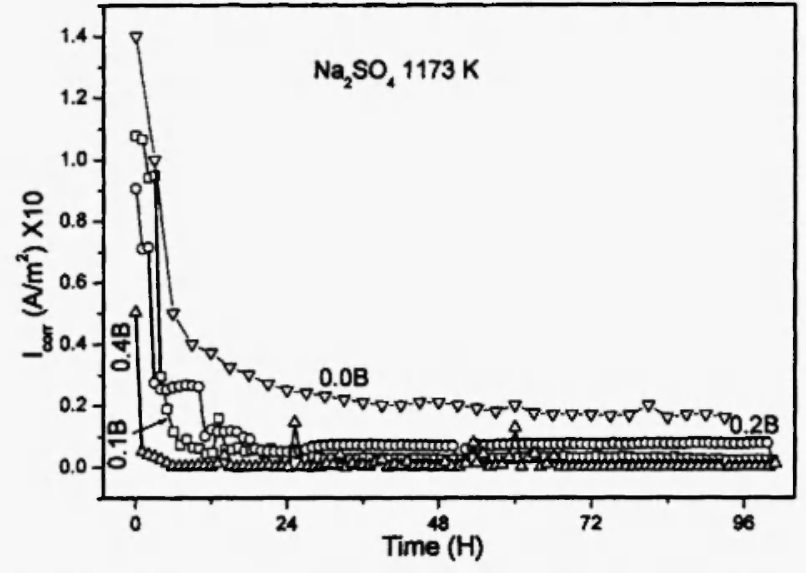

Fig. 7: Change in $I_{\text {corr }}$ with time for Fe40Al-base intermetallics in $\mathrm{Na}_{2} \mathrm{SO}_{4}$ at $1173 \mathrm{~K}$.

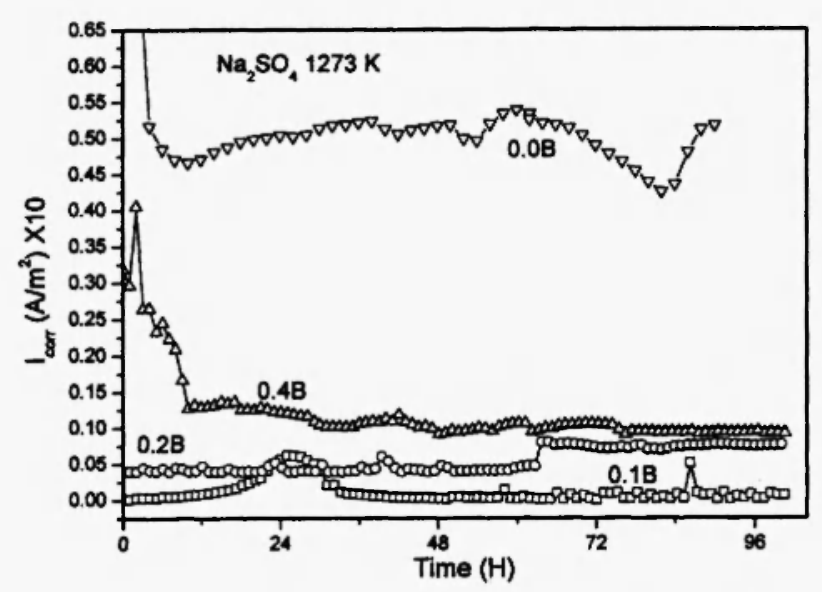

Fig. 8: Change in $\mathrm{I}_{\text {corr }}$ with time for Fe40Al-base intermetallics in $\mathrm{Na}_{2} \mathrm{SO}_{4}$ at $1273 \mathrm{~K}$.

alloy most resistant was the one with $0.4 \mathrm{~B}$ and the least resistant was the one without B. At $1273 \mathrm{~K}$, however, the base material had higher corrosion rates, Fig. 8, and, although the alloy with $0.4 \mathrm{~B}$ had initially high $\mathrm{I}_{\text {corr }}$ values, the three alloys with boron had very constant corrosion rate values, close to each other, being the alloy without $\mathrm{B}$ again the least corrosion resistant followed by the one with $0.4 \mathrm{~B}$, whereas the one with 0.1 Bwas the most resistant. It seem that the optimum addition of $B$ which gives the best corrosion resistance is 0.1 , since additions of either 0.2 or $0.4 \%$ increase the corrosion rate values.
A cross section of the intermetallics freely corroded in $\mathrm{Na}_{2} \mathrm{SO}_{4}$ at 1173 and $1273 \mathrm{~K}$ during five days and their $\mathrm{X}$-ray mappings of $\mathrm{Al}$, and $\mathrm{S}$ are presented in Figs. 9 and 10 respectively. In both cases, the external layer consisted mainly of $\mathrm{Al}$ and $\mathrm{S}$. Sulfur penetrated into the alloy through the Al-containing layer, dissolving it and corroded the substrate. The presence of $S$ on the grain boundaries in high concentrations obtained is a characteristic of internal sulfidation generated by sulfates 11 . Some dark particles are also seen, and an EDX analysis showed that they contained $\mathrm{Al}$ and $\mathrm{O}$, which means that they were alumina particles. In the indications observed at $1173 \mathrm{~K}$ on the iron aluminides, they contained aluminium and sulphur (Figs. 9 and 10), under a layer of external aluminium oxide which is probably in the form of $\mathrm{Al}_{2} \mathrm{O}_{3} / 14 /$. Sulfur moves from the oxide/ molten-salt interface towards the metal/oxide interface by diffusion, or infiltration of the melt through the structure defects of the scale, and there preferably reacts with the aluminium (of more activity) to form aluminium and sulphur compounds, presumably $\mathrm{Al}_{2} \mathrm{~S}_{3}$ /15/. Sodium was related neither in the protective scales nor inside the pits. At $1173 \mathrm{~K}$ the three alloys developed a protective layer of $\mathrm{Al}_{2} \mathrm{O}_{3}$, which maintained the corrosion rate values at lower levels in relation to those obtained at $1273 \mathrm{~K}$.

The chemical analysis done on the Fe40Al $+10 \mathrm{Al}_{2} \mathrm{O}_{3}+0.1 \mathrm{~B}$ alloy did not show $\mathrm{Na}$ as a component on the scale. This can be an indication of the lower corrosion rate exhibited by this material during the first $\mathbf{5 0}$ hours of testing, which was due to the basic character of the salt. The sulfidation could be due to the presence of $\mathrm{SO}_{3}$ from the decomposition of $\mathrm{Na}_{2} \mathrm{SO}_{4}$, taking a sour and aggressive gradient on the interface metal/scale, and a preferential attack in the grain boundaries of the alloy. On the same form, the external layer is rich in $\mathrm{Al}$ and was related with $\mathrm{S}$. The scale was detached from the alloy due to the infiltration of the molten $\mathrm{Na}_{2} \mathrm{SO}_{4}$ that is in contact with the alloy, and that might be the reason why that material presented high corrosion values. The elements present in the materials corroded at $1273 \mathrm{~K}$ showed important contents of $\mathrm{Al}$ and $\mathrm{S}$, and the depletion of $\mathrm{Fe}$ in these areas is evident, which could happen because it diffuses towards the scale and later on into the molten salts. 


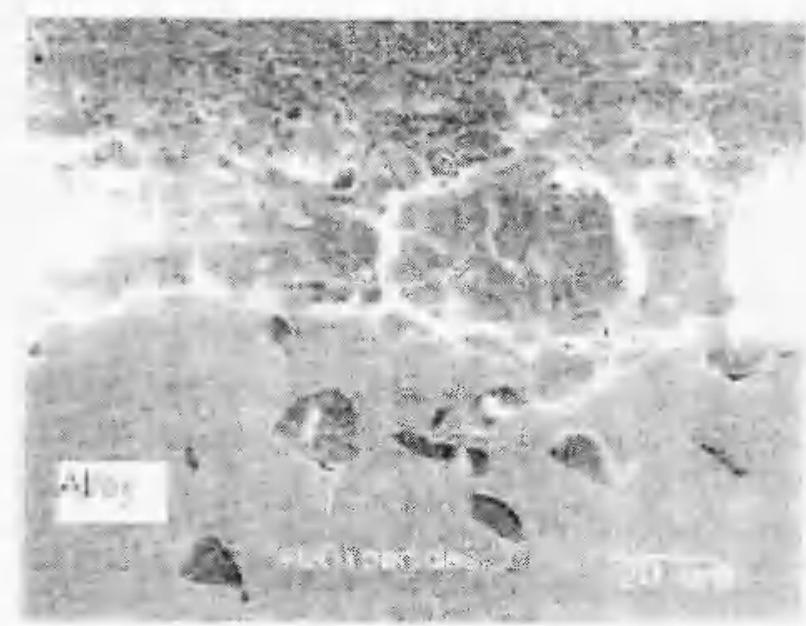

(a)

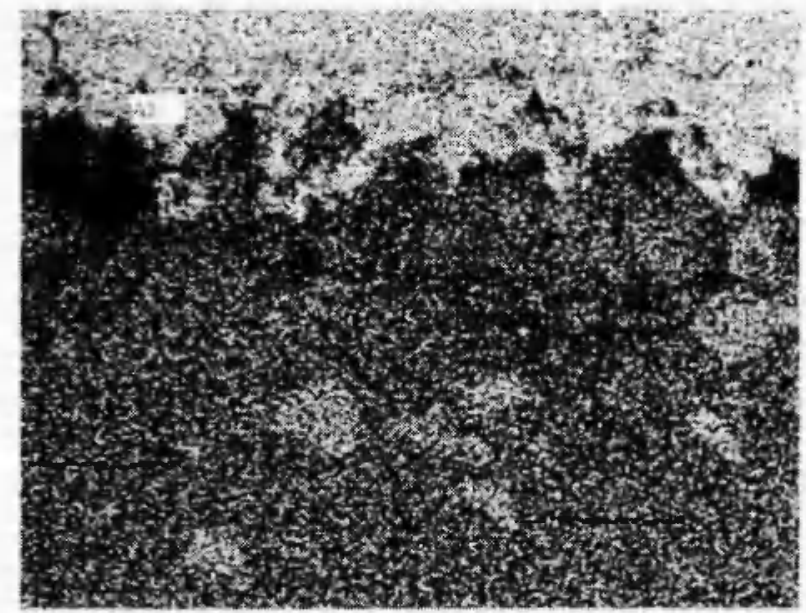

(b)

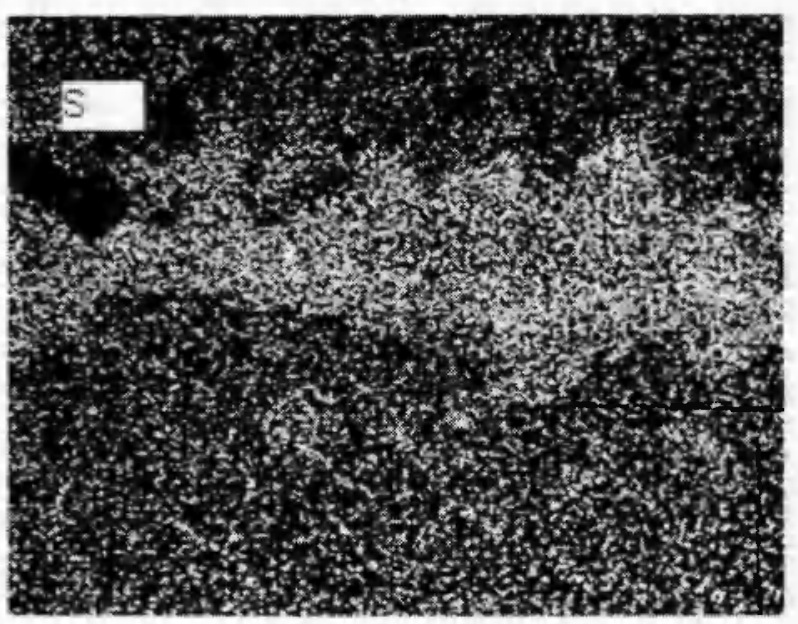

(c)

Fig. 9: (a) Photomicrograph of $\mathrm{Fe} 40 \mathrm{Al}+10 \mathrm{Al}_{2} \mathrm{O}_{3}+0.1 \mathrm{~B}$ alloy freely corroded in $\mathrm{Na}_{2} \mathrm{SO}_{4}$ at $1173 \mathrm{~K}$ during 5 days and chemical mappings of $b$ ) Aluminum and c) Sulfur.

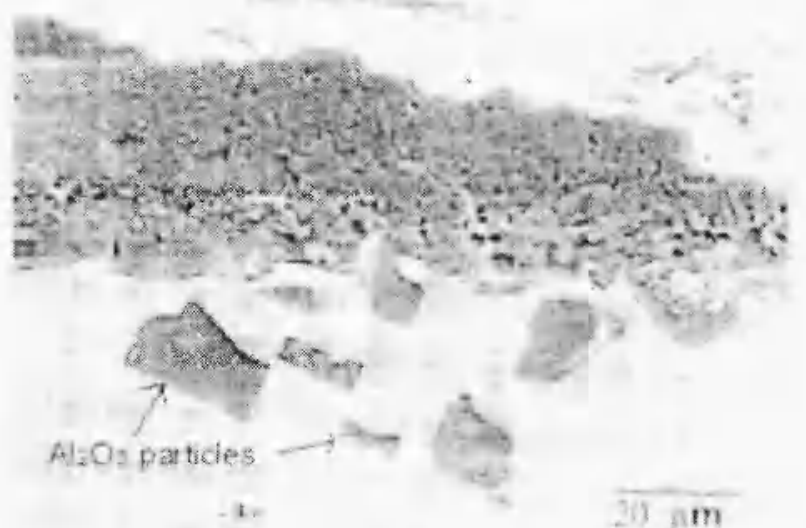

(a)

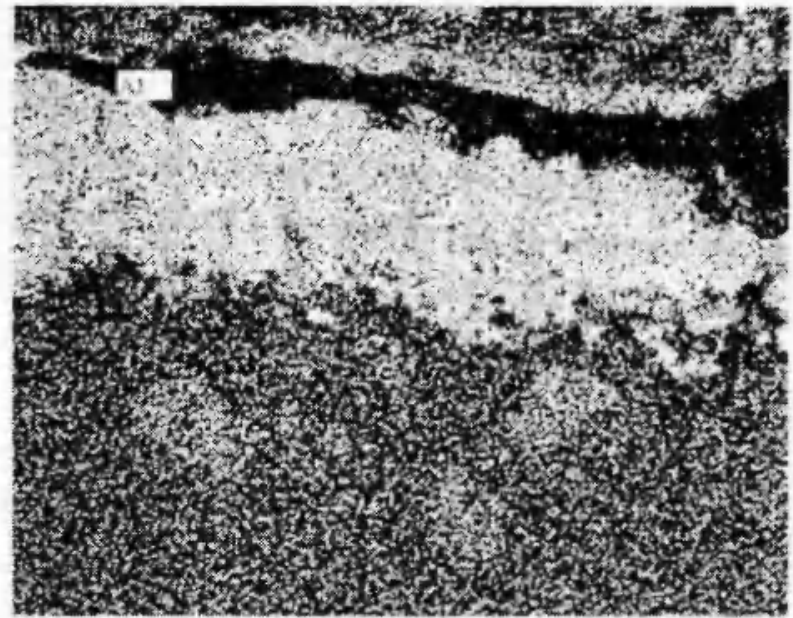

(b)

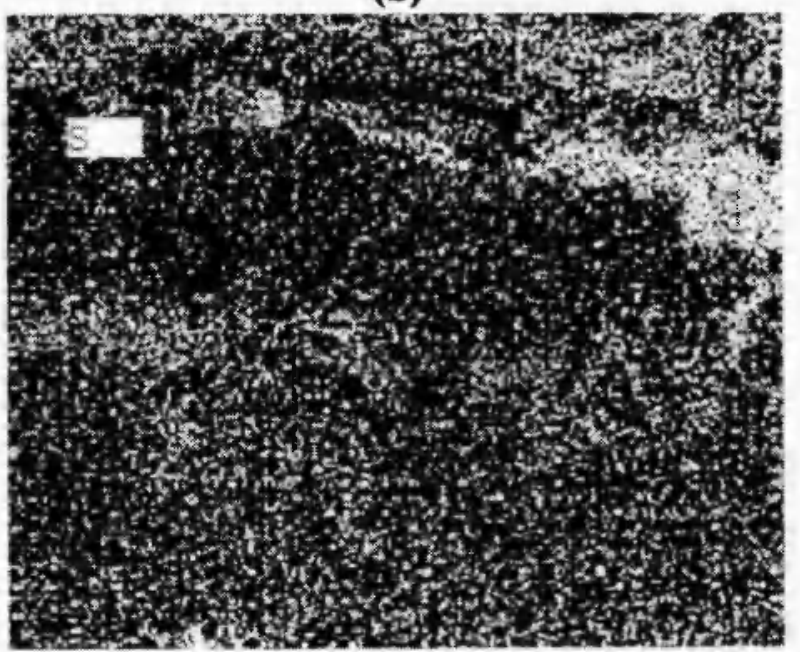

(c)

Fig. 10: (a) Photomicrograph of $\mathrm{Fe} 40 \mathrm{Al}+10 \mathrm{Al}_{2} \mathrm{O}_{3}$ $+0.2 \mathrm{~B}$ alloy freely corroded in $\mathrm{Na}_{2} \mathrm{SO}_{4}$ at $1273 \mathrm{~K}$ during 5 days and chemical mappings of b) Aluminum and c) Sulfur. 


\section{DISCUSSION}

The degradation of the Fe40Al base intermetallics can be explained based on its electrochemical mechanism. In general, any process of corrosion to high temperature depends on two electrochemical reactions, that is to say, the oxidation of the metal, which can take the place of an anode to form metal ions,

$$
M \rightarrow M^{2+}+2 e^{-}
$$

and the reduction of the species oxidizers in the cathode taking to the reduction of species,

$$
\text { Ox }+ \text { ne } \rightarrow \text { Red }
$$

These two reactions can be measured by using the corrosion current density. During the corrosion process, all the electrons are given of the anodic reactions and they are consumed by the cathodic reactions. As a result, the system of the electrode will have mixed potentials in its potential of corrosion. At this potential, the reaction of the anodic process is similar to the cathodic reaction. The current density corresponding to this reaction regimen can be examined by electrochemical methods as it is it the method of LPR. The corrosion current measured can be converted this way to instantaneous corrosion rate measurements of the material.

With the establishment of the $\mathrm{Al}_{2} \mathrm{O}_{3}$ layer, the corrosion rate decreases. The predominant surface product that forms between 873 and $1273 \mathrm{~K}$ has been reported to be $\alpha-\mathrm{Al}_{2} \mathrm{O}_{3}, / 16 /$, but it is quite possible for $\gamma-\mathrm{Al}_{2} \mathrm{O}_{3}$ or $\theta-\mathrm{Al}_{2} \mathrm{O}_{3}$ to exist in this temperature range /17/. These forms of alumina are the fast growing, more voluminous, more porous and less protective than $\alpha$ $\mathrm{Al}_{2} \mathrm{O}_{3} / 18 \%$. The temperature at which there is a transition from other types of alumina to the slower growing $\alpha-\mathrm{Al}_{2} \mathrm{O}_{3}$ appears to be $1173 \mathrm{~K} / 19 /$. On the other hand, the formation of $\mathrm{Al}_{2} \mathrm{O}_{3}$ consumes a certain quantity of $\mathrm{Al}$, reducing its activity and partial pressure of the oxygen. This causes a relative increase in the activities of the $\mathrm{Fe}$ and the $\mathrm{S}$, driving them to react with the molten mixture and to obtain a compound such as FeS.

The corrosive activity of a mixture depends on its electric conductivity. As is to be expected, as the temperature is increased, the mobility of the ions of the salt is increased, and thus also the conductivity. Zheng $/ 14$ / found that the conductivity of a mixture of $\mathrm{Na}_{2} \mathrm{SO}_{4}-$ (mass.\% 0-30) $\mathrm{NaVO}_{3}$ was increased with the temperature in a range from 1150 to $1220 \mathrm{~K}$. Another important characteristic of the molten salts was their character acid-basic, where the $\mathrm{SO}_{3}(\mathrm{~g})$ is the sour component in the sulphates. These characteristics, based on the concept of their ability to donate load or to accept it electronically, suggest that, for example in the molten $\mathrm{Na}_{2} \mathrm{SO}_{4}$, it has the following balance:

$$
\mathrm{Na}_{2} \mathrm{SO}_{4} \rightarrow \mathrm{Na}_{2} \mathrm{O}+\mathrm{SO}_{3}(\mathrm{~g}),
$$

and the activity parameters and partial pressure are:

$$
\begin{aligned}
& \log \mathrm{a}_{\mathrm{Na} 2 \mathrm{O}}+\log \mathrm{P}_{\mathrm{SO}_{3}}=\Delta \mathrm{G}_{2}{ }^{\circ} / 2.303 \mathrm{RT} \\
& =-16.7 \text { at } 1200 \mathrm{~K} .
\end{aligned}
$$

where the parameter $-\log a_{\mathrm{Na} 2 \mathrm{O}}$ can be taken as a measure of the salt basicity. In accordance with the previous expressions, is obvious to consider to $-\log$ $\mathrm{a}_{\mathrm{Na} 2 \mathrm{O}}$ (basicity) and $\log \mathrm{P}_{\mathrm{SO} 3}$ (acidity) for $\mathrm{Na}_{2} \mathrm{SO}_{4}$, besides the partial pressure of the $\mathrm{SO}_{3}$ in balance with $\mathrm{Na}_{2} \mathrm{SO}_{4}$ fixed the activity of $\mathrm{Na}_{2} \mathrm{O}$ or the melting basicity /19-21/. Keeping in mind that balance in the molten salt, the following reactions can be presented in the metallic interface:

$$
2 \mathrm{FeAl}+\mathrm{SO}_{3}(\mathrm{~g}) \rightarrow \mathrm{Al}_{2} \mathrm{O}_{3}+\mathrm{S}+2 \mathrm{Fe},
$$

which generates the conditions for reaction carried out:

$$
\mathrm{S}+\mathrm{Fe} \rightarrow \mathrm{FeS},(8)
$$

and in the oxide/molten salt interface the basic dissolution for reaction occurs $/ 17 /$ :

$$
\mathrm{Al}_{2} \mathrm{O}_{3}+\mathrm{Na}_{2} \mathrm{O} \rightarrow 2 \mathrm{NaAlO}_{2}
$$

The hot corrosion in molten salts usually exhibits selective attack and internal oxidation. The scale dissolution in a melt, in terms of the acidity or basicity of the salt, results in the film becoming less protective, and the corrosion rate is increased. In addition to the 
dissolution of the protective scales, there appeared to be a dissociation of the $\mathrm{Na}_{2} \mathrm{SO}_{4}$, increasing the concentrations of $\mathrm{Na}_{2} \mathrm{O}$ in the melt, and later on, with diffusion of $\mathrm{Na}$ and $\mathrm{S}$, an increase of these elements in the metal/scale interface. This caused the detachment and cracking of the protective scale, allowing the corrosion of the material. This phenomenon was equally observed on the other intermetallic materials at $1273 \mathrm{~K}$ which presented high corrosion rates and a significant metal degradation. This explains the values of the anodic current density values that were observed in Figs. 3 and 4.

\section{CONCLUSIONS}

The results of exposing atomized Fe40Al-base intermetallics to molten $\mathrm{Na}_{2} \mathrm{SO}_{4}$ have shown that, at both 1173 and $1273 \mathrm{~K}$, the $\mathrm{Fe} 40 \mathrm{Al}+10 \mathrm{Al}_{2} \mathrm{O}_{3}$ material exhibited a higher corrosion rate than those alloyed with boron. The additions of up to $0.4 \mathrm{~B}$, for short times made the $E_{\text {cor }}$ value more active but after some hours, all the $E_{\text {corr }}$ values became more noble, even nobler than the alloy without boron. None of the alloys showed a passive region, at least at short times. In terms of corrosion rate, additions of boron always decreased this value as opposed to the alloy without boron, especially at $1273 \mathrm{~K}$, but the corrosion rate values decreased rapidly, attaining a constant value, which was consistent with the establishment of a protective alumina, $\mathrm{Al}_{2} \mathrm{O}_{3}$ layer, and promoted an $\mathrm{Al}$ depletion on the $\mathrm{FeAl}$ matrix which allowed internal sulfides formation.. It seems that the optimum amount of boron that gives the best corrosion resistance is $0.1 \mathrm{~B}$

\section{ACKNOWLEDGEMENTS}

The authors wish to express thanks to Miss $\mathrm{H}$. Esparza Ponce from CIMAV by her technical support in the SEM and electrochemical work.

\section{REFERENCES}

1. Metals Handbook, Ninth Edition, Vol. 13, "HighTemperature Corrosion in Molten Salts", ASM
International, 1987, p.50-55.

2. A. Pardo, E. Otero, F. J. Perez, I. F. Alvarez and M. V. Utrilla, Rev. Metal., 29(5), 300-306. (1993),

3. E. Otero, A. Pardo, J. Hernandez and P. Hierro, Rev. Metal. 26(1), 26-30, (1990).

4. J. Klower, Proceedings 2nd Intern. Conference Heat-Resistant Materials, Gatlinburg, Tennessee, 11-14 September, (1995), p.245-252.

5. A. Nishikata and S. Haruyama, Corrosion, 42,(10), 576-584 (1986),

6. P. F. Tortorelli and K. Natesan, Mater. Sci. and Eng., A258, 115-125 (1998).

7. L. Martinez, M. Amaya, J. Porcayo-Calderon and E. J. Leverina, Mater. Sci. and Eng., A258 306312 (1998).

8. M.A. Espinosa-Medina, M. Casales, A. MartinezVillafante, J. Porcayo-Calderon, L Martinez and J.G. Gonzalez-Rodriguez, Mater. Sci. and Eng. A300, 183-189 (2001).

9. P. F. Tortorelli and P. S. Bishop, in: R. H. Jhones and R. E. Ricker (Eds.), Environmental Effects on Advanced Materials, The Minerals, Metals and Materials Society, Warrendale, P.A., (1991), p.9197.

10. J. C. Newcombe, D. L. Grimmet and R. L. Gray, Energy Technology Engineering Center, report 022-ZR-004, Canoga Park, CA, (1995).

11. H. J. Ratzer-Schoibe, 4th International Symposium on High Temperature Corrosion and Protection of Materials, les EMBIEZ (Var) France.(1996).

12. L. Martinez, O. Flores, M. Amaya, A. Duncan, S. Viswanathan, D. Lawrynowics and E. J. Lavernia, J. of Mater. Synth. Processing, 5(1), 65-76 (1997).

13. M. Stearn and A.L. Geary, J. Electrochem. Soc., 105(3) 638-645 (1958).

14. X. Zheng, R. A. Rapp and K. Goto, $J$. Electrochem. Soc. 140(5), 1330-1334 (1993).

15. W. Kai, R. T. Huang, Oxid. Met. 48(1), 59-64 (1997).

16. P. C. Patnaik, W. W. Smeltzer, J. Electrochem. Soc. 132(5), 1226-1232 (1985).

17. W. D. Halstead, "Progress Review No.70", J. of the Institute of Fuel, 234-239, July (1970).

18. J.D.K. Grupta and R. A. Rapp, J. Electrochem. Soc., 132(3), 735-737 (1985).

19. M. Sakiyama, P. Thomaszeweiz and G. R. 
Wallwork, Oxid. Met. 13(2), 311-317 (1979).

20. B. A. Pint, in: D.A. Shores, R.A. Rapp, P.Y. Hou (Eds.), Fundamental Aspects of High Temperature Corrosion, The Electrochemical Society, Pennington, N.J., 74-79 (1997).

21. K. Natesan, Mater. Sci. Eng. A258, 126-134 (1998). 
